\title{
PELATIHAN DARING TEKNOLOGI PEMBELAJARAN
}

\author{
Tabah Heri Setiawan'), Aden ${ }^{2)}$, Andi Nur Rahman ${ }^{3)}$ \\ 1,2,3 Program Studi Matematika, Fakultas Matematika dan Ilmu Pengetahuan Alam, Universitas Pamulang
}

\begin{abstract}
Abstrak
Tujuan dari kegiatan pengabdian kepada masyarakat adalah untuk melaksanakan Tridharma Perguruan Tinggi, selain itu diharapkan dengan pengabdian kepada masyarakat tersebut maka keberadaan perguruan tinggi dapat memberikan kontribusi besar kepada pengembangan dan penerapan keilmuan kepada masyarakat. Pada masa pandemi COVID 19 ini maka segala aktifitas belajar mengajar di sekolah ditiadakan demi memutus mata rantai virus COVID 19 ini dan menggantinya dengan kegiatan belajar dan mengajar dari rumah secara online (daring). Sebagian besar pihak sekolah belum mengetahui bagaimana caranya melaksanakan sistem pembelajaran daring dikarenakan tidak adanya pelatihan tersebut sehingga pelaksanaan pembelajaran daring dilaksanakan seadanya melalui media sosial. Oleh karena itu perlu adanya pelatihan daring teknologi pembelajaran di sekolah agar pelaksanaan pembelajaran secara daring dapat lebih maksimal. Pelatihan daring teknologi pembelajaran ini meliputi cara membuat peta konsep dengan iMindMap untuk proses pembelajaran, mengoptimalkan Learning Management System (LMS), dan Komputasi awan untuk pendidikan (Clouding Computing for Education). Ketiga materi pelatihan daring ini berkaitan erat dalam pembelajaran secara daring dan perlu dipahami oleh guru-guru dan pihak sekolah agar proses pembelajaran dari rumah dapat terlaksana dengan baik dan menghasilkan hasil pembelajaran yang maksimal.
\end{abstract}

Kata Kunci: iMindMap, Komputasi Awan, LMS

\begin{abstract}
The purpose of community service activities is to carry out the Tridharma of Higher Education, in addition it is hoped that with this community service, the existence of universities can make a major contribution to the development and application of science to the community. During the COVID 19 pandemic, all teaching and learning activities in schools were eliminated in order to break the chain of the COVID 19 virus and replace it with learning and teaching activities from home online (online). Most of the schools do not know how to implement an online learning system because there is no training so that online learning is carried out improperly through social media. Therefore it is necessary to have online learning technology training in schools so that the implementation of online learning can be maximized. This learning technology online training includes how to create concept maps with iMindMap for the learning process, optimize the Learning Management System (LMS), and cloud computing for education (Clouding Computing for Education). These three online training materials are closely related to online learning and need to be understood by teachers and schools so that the learning process from home can be carried out properly and produce maximum learning results.
\end{abstract}

Keywords: iMindMap, Clouding Computing, LMS

Correspondence author: Tabah Heri Setiawan, tabah.ibnubara@gmail.com, South Tangerang, Indonesia 


\section{PENDAHULUAN}

\subsection{Latar Belakang}

Pelaksanaan Kegiatan Belajar Mengajar (KBM) di sekolah merupakan kegiatan yang harus dilakukan setiap sekolah demi tercapainya tujuan pembelajaran yakni dengan melakukan tatap muka di kelas, pemberian materi pembelajaran dan diskusi di kelas, adanya interaksi secara langsung antara murid dengan guru di kelas dan sebagainya sehingga Kegiatan Belajar Mengajar di sekolah terlaksana sebagaimana mestinya.

Akan tetapi karena adanya Pandemi COVID-19 ini maka Kegiatan Belajar Mengajar (KBM) di sekolah tidak dapat terlaksana demi memutuskan rantai penyebaran virus COVID-19 ini. Oleh karena itu sekolah di himbau oleh pemerintah untuk melaksanakan Kegiatan Belajar Mengajar dari rumah atau dilaksanakan secara daring. Meskipun demikian secara garis besar Indonesia belum siap terapkan pendidikan berbasis daring (Bona, t.t.) salah satu indikatornya adalah belum semua wilayah siap untuk menerapkan pendidikan dalam jaringan (ABC, 2020) karena akses internet juga belum merata di Indonesia, sementara itu untuk melakukan pembelajaran daring diperlukan koneksi internet yang minimal untuk berkirim materi, tugas dan penilaian.

Bagi daerah atau wilayah yang sudah terjamah internet, bukan berarti mudah dalam menerapkan pembelajaran jarak jauh melalui daring, konsep pembelajaran daring merupakan konsep yang tidak mudah dan banyak kendala yang akan dihadapi oleh siswa, guru, orang tua maupun pihak sekolah (Rezkisari, 2020) bahkan guruguru pun minim mendapatkan pelatihan bagaimana cara melaksanakan Kegiatan Belajar Mengajar (KBM) secara daring dari rumah (Nursalikah, 2020). Untuk itu perlu adanya pelatihan kepada guru-guru demi terlaksananya Kegiatan Belajar Mengajar (KBM) secara daring dari rumah dengan baik sehingga tercapailah tujuan pembelajaran yang diinginkan.

Sekolah Dasar Al - Fath Bumi Serpong Damai merupakan salah satu sekolah yang menerapkan sistem pembelajaran online menggunakan Learning Management System (LMS) berbasis Moodle demi terlaksananya Kegiatan Belajar Mengajar (KBM) secara daring dari rumah. Akan tetapi pembekalan penggunaan LMS kepada guru-guru SD Al-Fath ini dirasa kurang dan perlu adanya pelatihan tambahan agar guru-guru dapat mengoptimalkan aplikasi tersebut dalam proses pembelajaran.

Sebagai sekolah yang menerapkan pembelajaran secara aktif learning sudang menjadi hal biasa menggunakan mind mapping sebagai salah satu model pembelajaran yang diterapkan pada hari biasa saat tatap muka sebelum pandemi Covid-19. Selama ini penyusunan mind mapping dilakukan secara sederhana dengan menggunakan kertas karton, akan tetapi ketika terjadi pandemi Covid-19 seperti saat ini, mau tidak mau pembuatan mind mapping harus mulai dirubah secara digital dengan menggunakan piranti lunak mind mapping. Salah satu piranti lunak yang sering digunakan adalah iMindMap yang dicetuskan oleh Tony Buzan sebagai salah satu tokoh pengembang mind mapping. Oleh karena itu pelatihan menggunakan iMindMap sangat membantu guru-guru dalam membuat peta materi maupun peta pembelajaran selama pembelajaran daring.

Untuk memudahkan proses pertukaran informasi data, materi dan penilaian antar guru harus mulai meninggalkan cara konvensional menuju penggunakan 
teknologi awan (clouding computing) sehingga semua guru bisa saling berkolaborasi dalam sharing file maupun penyusunan materi secara bersama-sama secara daring. Sehingga kami menambahkan pelatihan dengan materi Clouding Computing for Education.

Oleh karena itu kami melakukan Pengabdian kepada Masyarakat (PkM) berupa "Pelatihan Daring Teknologi Pembelajaran" pada SD Al-Fath BSD, Kota Tangerang Selatan. Diharapkan dengan adanya pelatihan ini maka guru-guru di SD AL-Fath BSD dapat melaksanakan Kegiatan Belajar Mengajar (KBM) dengan maksimal dan dapat mencapai tujuan pembelajaran yang diharapkan selama pandemi Covid-19 dan dapat berbagi dengan sesama guru baik dalam satu gugus maupun dalam satu wilayah.

\subsection{Perumusan Masalah}

Berdasarkan latar belakang masalah tersebut maka dapat dirumuskan masalah sebagai berikut:

1). Bagaimana menerapkan metode pembelajaran dengan Mind Mapping melalui perangkat lunak iMindMap untuk memudahkan proses pembelajaran secara daring?

2). Bagaimana mengoptimalkan Learning Management System (LMS) khususnya yang berbasis Moodle untuk memudahkan tugas guru dalam memanajemen kelas?

3). Bagaimana Clouding Computing dapat dimanfaatkan oleh guru-guru sebagai sarana berkolaborasi secara daring?

\subsection{Tujuan Pengabdian Kepada Masyarakat}

Berdasarkan perumusan masalah di atas maka Pengabdian kepada Masyarakat (PkM) ini bertujuan untuk :

1). Mengetahui bagaimana menerapkan metode pembelajaran dengan Mind Mapping melalui perankat lunak iMindMap untuk memudahkan proses pembelajaran secara daring.

2). Mengetahui bagaimana mengoptimalkan Learning Management System (LMS) khususnya yang berbasis Moodle untuk memudahkan tugas guru dalam memanajemen kelas.

3). Mengetahui bagaimana Clouding Computing dapat dimanfaatkan oleh guruguru sebagai sarana berkolaborasi secara daring.

\subsection{Manfaat Pengabdian Kepada Masyarakat}

Manfaat adanya kegiatan Pengabdian kepada Masyarakat yang telah dilaksanakan adalah sebagai berikut

1). Guru dapat mengoptimalkan LMS yang selama ini hanya dimanfaatkan sebagai wadah mengirim tugas bagi guru serta wadah mengirim jawaban tugas guru untuk siswa, dapat dimanfaatkan untuk membuat quis, forum diskusi bahkan ujian semester dapat dilaksanakan denganLMS berbasis Moodle.

2). Dengan menguasai iMindMap guru dapat tetap melakukan pembelajaran daring dengan metode mind mapping (peta konsep) karena terintegrasi dengan segala media internet. 
3). Guru dapat saling berkolaborasi dalam menyusun tugas sekolah seperti RPP, Silabus, Materi Ajar secara bersama-sama dan berkolaborasi secara daring tanpa menunggu rekan yang lain selesai terlebih dahulu.

\subsection{Tinjauan Pustaka}

\subsubsection{Learning Management System dengan Moodle}

MOODLE (singkatan dari Modular Object-Oriented Dynamic Learning Environment) adalah paket perangkat lunak yang diproduksi untuk kegiatan belajar berbasis internet dan situs web yang menggunakan prinsip social constructionist pedagogy. MOODLE merupakan salah satu aplikasi dari konsep dan mekanisme belajar mengajar yang memanfaatkan teknologi informasi, yang dikenal dengan konsep pembelajaran elektronik atau $e$ learning (Surjono, 2013). Moodle dapat digunakan secara bebas sebagai produk sumber terbuka (open source) di bawah lisensi GNU. Moodle dapat diinstal di komputer dan sistem operasi apapun yang bisa menjalankan PHP dan mendukung database SQL (wikipedia, 2020a).

Di dunia e-learning Indonesia, Moodle lebih dikenal fungsinya sebagai Course Management System atau "Learning Management System"(LMS). Dengan tampilan seperti halaman web pada umumnya, Moodle memiliki fitur untuk menyajikan kelas (course), dimana pengajar bisa mengunggah materi ajar, soal dan tugas. Murid bisa masuk log ke Moodle kemudian memilih kelas yang disediakan atau didaftarkan (enrol) untuknya. Aktivitas murid di dalam Moodle ini akan terpantau progress dan nilainya. Di Indonesia sendiri, diketahui bahwa Moodle telah dimanfaatkan untuk sekolah menengah, perguruan tinggi dan perusahaan.

\subsubsection{Peta Pikiran (Mind Mapping)}

Mind Maping pertama kali dikembangkan oleh Tony Buzan, seorang Psikolog dari Inggris. Beliau adalah penemu Mind Map (Peta Pikiran), Ketua Yayasan Otak, pendiri Klub Pakar (Brain Trust) dan pencipta konsep Melek Mental. Mind map diaplikasikan di bidang pendidikan, seperti teknik, sekolah, artikel serta menghadapi ujian. (Riadi, 2014)

Mind maping dapat diartikan sebagai proses memetakan pikiran untuk menghubungkan konsep-konsep permasalahan tertentu dari cabang-cabang sel saraf membentuk korelasi konsep menuju pada suatu pemahaman dan hasilnya dituangkan langsung di atas kertas dengan animasi yang disukai dan gampang dimengerti oleh pembuatnya. Sehingga tulisan yang dihasilkan merupakan gambaran langsung dari cara kerja koneksi-koneksi di dalam otak.

Mind maping adalah cara mengembangkan kegiatan berpikir ke segala arah, menangkap berbagai pikiran dalam berbagai sudut. Mind maping mengembangkan cara berpikir divergen dan berpikir kreatif. Mind mapping yang sering kita sebut dengan peta konsep adalah alat berpikir organisasional yang sangat hebat yang juga merupakan cara termudah untuk menempatkan informasi ke dalam otak dan mengambil informasi itu ketika dibutuhkan (Buzan, 2008). 
Menurut Tony Buzan, Mind Maping dapat membantu kita untuk banyak hal seperti: merencanakan, berkomunikasi, menjadi lebih kreatif, menyelesaikan masalah, memusatkan perhatian, menyusun dan menjelaskan pikiran-pikiran, mengingat dengan baik, belajar lebih cepat dan efisien serta melatih gambar keseluruhan. Ada sebuah program mind mapping yang dikeluarkan oleh ThinkBuzan yaitu iMindMap. Aplikasi ini dikembangkan dengan menggunakan metode Mind Mapping atau pemetaan pikiran yang biasa digunakan untuk brainstorming, pengorganisasian, pemikiran kreatif, dan rancangan serta perencanaan berbagai macam hal. Aplikasi ini dikembangkan oleh ThinkBuzan Ltd. Buzan's iMindMap dapat digunakan dengan menggunakan perangkat lunak seperti Microsoft Windows, Macintosh, Mac OS X dan Linux. Perangkat lunak ini memungkinkan untuk pembuatan peta pemikiran dengan menggunakan perangkat keras yang ada di komputer seperti tetikus, papan ketik, komputer berbentuk tablet atau interactive white board.

Beberapa manfaat metode pencatatan menggunakan mind mapping, antara lain:

1). Tema utama terdefinisi secara sangat jelas karena dinyatakan di tengah.

2). Level keutamaan informasi teridentifikasi secara lebih baik. Informasi yang memiliki kadar kepentingan lebih diletakkan dengan tema utama.

3). Hubungan masing-masing informasi secara mudah dapat segera dikenali.

4). Lebih mudah dipahami dan diingat.

5). Informasi baru setelahnya dapat segera digabungkan tanpa merusak keseluruhan struktur mind mapping, sehingga mempermudah proses pengingatan.

6). Masing-masing mind mapping sangat unik, sehingga mempermudah proses pengingatan.

7). Mempercepat proses pencatatan karena hanya menggunakan kata kunci.

\subsubsection{Komputasi Awan (Clouding Computing)}

Cloud Computing merupakan istilah dari Cloud diartikan sebagai internet dan Computing diartikan sebagai komputer. Definisi dari Cloud Computing adalah sebuah proses pengolahan daya komputasi melalui jaringan internet yang memiliki fungsi agar dapat menjalankan program melalui komputer yang telah terkoneksi satu sama lain pada waktu yang sama.

Cloud Computing merupakan sebuah teknologi yang menjadikan internet sebagai pusat server untuk mengelola data dan juga aplikasi pengguna. Cloud Computing memudahkan penggunanya untuk menjalankan program tanpa harus menginstall aplikasi terlebih dahulu dan memudahkan pengguna untuk mengakses data dan informasi melalui internet. Berikut ini beberapa manfaat dari Cloud Computing, yaitu :

1). Media Penyimpanan Terpusat pada Server

Teknologi Cloud Computing memudahkan pengguna untuk menyimpan data secara terpusat di satu server sesuai layanan yang sudah disediakan oleh Cloud Computing. Selain itu, dari segi infrastruktur pengguna tidak tidak perlu lagi menyediakannya seperti data center, 
media penyimpanan, sudah tersedia secara virtual oleh Cloud Computing.

2). Keamanan Data

Dalam penerapan teknologi Cloud Computing penyedia Cloud Computing telah menyediakan jaminan data sehingga data tidak mudah corrupt atau rusak, platform teknologi, jaminan ISO. Tentunya dengan Cloud Computing akan membuat data dan informasi Anda bisa lebih aman terjaga dibandingkan metode konventional yang digunakan oleh kebanyakan orang saat ini.

3). Lebih Murah dan Tahan Lama

Cloud Computing tidak memerlukan media penyimpanan storage pada hard disk eksternal karena sudah ada media penyimpanan terpusat pada server. Karena semua produk hardware atau fisik memiliki masa pemakaian dan setelah masa pemakaian tersebut biasanya akan terjadi beberapa kerusakan dan berfungsi tidak optimal dan sering terjadi error.

\section{METODE PELAKSANAAN}

\subsection{Kerangka Pemecahan Masalah}

Masalah yang dihadapi oleh guru-guru sebagian besar dalam menghadapi fenomena sekolah dari rumah (School From Home) adalah belum siapnya guru-guru dalam menyiapkan model, metode maupun teknik pembelajaran yang sesuai dengan pendidikan jarak jauh. Ada beberapa poin yang menjadi kendala guru dalam menerapkan pembelajaran dari rumah salah satunya penguasaan dalam memanajemen kelas secara daring yang biasa dikenal sebagai Learning Management System (LMS). Untuk beberapa sekolah telah menyiapkan learning management system yang sudah terintegrasi salah satunya dengan menggunakan moodle, bagi yang belum memiliki learning management system sendiri dapat menggunakan learning management system yang disediakan oleh beberapa platform seperti Google Classroom, Microsoft Teams, Edmodo, Schoology dan lain sebagainya.

Meskipun demikian pendampingan maupun pelatihan perlu dilakukan mengingat learning management system merupakan suatu sistem yang harus dibangun secara utuh dari proses perencanaan, pelaksanaan, sampai pada tahap evaluasi pembelajaran. Untuk SD Al-Fath BSD LMS yang digunakan sudah menggunakan moodle yang terintegrasi antar kelas dan antar pendidik. Akan tetapi karena kondisi pandemi yang sangat mendadak sehingga learning management system ini belum disosialisasikan secara utuh kepada guru-guru sehingga guru merasa kesulitan dalam menggunakan learning management system. Oleh karena itu tim pengabdi dari Universitas Pamulang khususnya dari Program Studi Matematika menyelenggarakan pelatihan yang salah satu temanya adalah Optimalisasi Learning Management System, dengan harapan semua guru dapat memanfaatkan semua fitur yang ada pada learning management system.

Selain itu terkait dengan metode pembelajaran SD al-fath BSD salah satu sekolah yang berbasis active learning dan salah satu metode yang biasa digunakan adalah menggunakan peta konsep atau peta pikiran (mind mapping) dalam 
mengembangkan pembelajaran berbasis active learning. Selama ini dengan pertemuan tatap muka pelaksanaan metode active learning dilakukan dengan menggambar pada kertas karton ataupun media lainnya sebagai bagian dari bentuk kreativitas dan melatih psikomotorik peserta didik. Dikarenakan pandemi ini cukup panjang dan akan berakhir sampai tahun 2020 maka media menyusun peta pikiran harus mulai dikonversi ke dalam bentuk digital dengan menggunakan berbagai piranti lunak. Oleh karena itu salah satu materi pengabdian berisi tentang yang iMindMap yang dikeluarkan oleh Tony buzan yakni sebuah perangkat lunak yang dipakai untuk membuat peta pikiran.

Selanjutnya terkait dengan fleksibilitas guru dalam berbagi ilmu maupun berbagi tugas secara bersama-sama yang biasa dilakukan melalui rapat maupun kegiatan bersama di sekolah dikarenakan pandemi covid 19 maka perlu adanya penggunaan suatu teknologi terkini untuk memfasilitasi guru guru dalam melakukan kolaborasi tugas maupun kolaborasi kegiatan. dan salah satu teknologi terkini yang dapat dimanfaatkan untuk berkolaborasi antar guru secara daring adalah melalui komputasi awan atau cloud computing. Dengan adanya cloud computing maka mampu menjawab tuntutan dalam menyiapkan atau menyusun bahan bahan ajar ataupun dokumen-dokumen yang diperlukan dalam proses pembelajaran. salah satu materi dalam pengabdian ini adalah penggunaan komputasi awan untuk pendidikan (cloud computing for education).

\subsection{Realisasi Pemecahan Masalah}

Untuk memecahkan masalah yang dihadapi oleh guru SD Al-Fath BSD maka kami melakukan pelatihan serta pendampingan kepada guru-guru SD Al-Fath BSD. Untuk pelatihan pendampingan dilakukan secara daring mengingat kondisi masih pandemi Covid 19 dimana semua kegiatan yang mengumpulkan banyak massa dilarang oleh pemerintah. Meskipun demikian tidak menghalangi semangat tim pengabdi maupun guru-guru untuk melaksanakan kegiatan pelatihan secara daring. Dengan menggunakan aplikasi zoom maka kegiatan ini dapat berjalan layaknya video conference dan peserta bisa langsung melakukan simulasi atau praktik dari materi yang tim pengabdi sampaikan karena semuanya berbasis komputer. Jika ada kendala dalam penggunaan aplikasi sebagaimana tersebut di atas maka peserta pelatihan dan pemdampingan dapat langsung bertanya selayaknya pertemuan tatap muka.

\subsection{Khalayak Sasaran}

Target sasaran pada kegiatan pengabdian kepada masyarakat kali ini adalah semua guru yang mengajar di SD Al-Fath BSD baik guru kelas, guru pendamping, maupun guru bidang studi. Total keseluruhan peserta yang mengikuti kegiatan ini sebanyak 83 peserta.

\subsection{Tempat dan Waktu}

Tempat kegiatan Pengabdian dilakukan di SD Al-Fath BSD yang terletak di Lengkong Gudang Timur, Serpong BSD. Akan tetapi mengingat kondisi yang tidak 
memungkinkan untuk berkerumun di satu tempat maka kegiatan dialihkan secara daring sesuai himbauan dan ajuran dari pemerintah melalui Zoom Meeting Cloud.

Waktu pelaksanaan pengabdian kepada masyarakat pada tanggal 3 sampai 5 Juli 2020 mulai pukul 08.00 - 11.00 WIB. $(\mathrm{PkM})$ :

Berikut rincian acara pelaksanaan kegiatan Pengabdian kepada Masyarakat

Tabel 1 Jadwal Kegiatan Pengabdian kepada Masyarakat

\begin{tabular}{|c|c|c|c|}
\hline \multicolumn{3}{|c|}{ Hari dan Tanggal Pelaksanaan } & Jumat, 3 Juli 2020 \\
\hline No. & Waktu & Susunan Acara & Pemateri / Penanggung Jawab \\
\hline 1 & $08.00-08.15$ & Pembukaan acara & MC (Andi Nur Rahman, S.Si., M.Pd) \\
\hline 2 & $08.15-08.30$ & $\begin{array}{l}\text { Sambutan Kaprodi } \\
\text { Matematika }\end{array}$ & Yulianti Rusdiana, S.Si., M.Sc. \\
\hline 3 & $08.30-08.45$ & $\begin{array}{l}\text { Sambutan Kepala } \\
\text { Sekolah }\end{array}$ & Sri Indarwati Candra, S.Si. \\
\hline 4 & $08.45-09.00$ & $\begin{array}{l}\text { Sambutan Ketua } \\
\text { Pelaksana }\end{array}$ & Tabah Heri Setiawan, S.Si., M.Pd. \\
\hline 5. & $09.00-11.00$ & $\begin{array}{l}\text { Penyampaian dan } \\
\text { Diskusi Materi } 1 \text { : } \\
\text { Optimalisasi Learning } \\
\text { Management System } \\
\text { (LMS) }\end{array}$ & Aden, S.Si., M.Pd \\
\hline 6. & $11.00-11.15$ & Penutupan Acara & MC (Andi Nur Rahman, S.Si., M.Pd) \\
\hline \multicolumn{3}{|c|}{ Hari dan Tanggal Pelaksanaan } & Sabtu, 4 Juli 2020 \\
\hline No. & Waktu & Susunan Acara & Pemateri / Penanggung Jawab \\
\hline 1 & $08.00-08.30$ & Pembukaan acara & MC (Aden, S.Si., M.Pd) \\
\hline 2 & $08.00-11.00$ & $\begin{array}{l}\text { Penyampaian dan } \\
\text { Diskusi Materi 2: } \\
\text { Metode Pembelajaran } \\
\text { dengan Mind Mapping }\end{array}$ & Tabah Heri Setiawan, S.Si., M.Pd \\
\hline 3 & $11.00-11.15$ & Penutupan Acara & MC (Aden, S.Si., M.Pd) \\
\hline \multicolumn{3}{|c|}{ Hari dan Tanggal Pelaksanaan } & Minggu, 5 Juli 2020 \\
\hline No. & Waktu & Susunan Acara & Pemateri / Penanggung Jawab \\
\hline 1 & $08.00-08.30$ & Pembukaan acara & MC (Aden, S.Si., M.Pd) \\
\hline 2 & $08.30-11.00$ & $\begin{array}{l}\text { Penyampaian dan } \\
\text { Diskusi Materi } 3 \text { : } \\
\text { Clouding Computing for } \\
\text { Education }\end{array}$ & Andi Nur Rahman, S.Si., M.Pd \\
\hline 3 & $11.00-11.15$ & Penutupan Acara & $\begin{array}{l}\text { MC (Aden, S.Si., M.Pd) } \\
\text { Tabah Heri Setiawan, S.Si., M.Pd Sri } \\
\text { Indarwati Candra, S.Si. }\end{array}$ \\
\hline
\end{tabular}




\subsection{Metode Kegiatan}

Sebagaimana diuraikan sebelumnya bahwa metode kegiatan ini berupa pelatihan dan pendampingan dalam menggunakan berbagai perangkat lunak seperti LMS (learning management system) berbasis model untuk manajemen kelas, penggunaan iMindMap untuk membuat peta pikiran atau mind mapping, dan penggunaan cloud computing atau komputasi awan untuk mengkolaborasikan kerja guru secara daring dengan mengambil contoh penggunaan Google Drive.

Pelatihan berupa pengenalan serta pendahuluan dari perangkat lunak yang akan digunakan setelah itu peserta diminta melakukan praktik langsung menggunakan piranti lunak yang sudah disebut di atas yang sebelumnya sudah dikirim oleh tim pengabdi kepada koordinator guru SD Al-Fath BSD.

Dalam proses pendampingan ini akan terjadi banyak interaksi yang sifatnya dua arah bila ada kendala ataupun pertanyaan yang sifatnya teknis penggunaan perangkat lunak tersebut.

Diakhir sesi semua peserta diminta memberikan umpan balik kepada tim pengabdi sebagai bahan evaluasi untuk tim pengabdi. Umpan balik berisi angket digital melalui google form dan wajib diisi oleh semua peserta pelatihan sebagai syarat memperoleh sertifikat dari tim pengabdi.

\section{HASIL DAN PEMBAHASAN}

Berdasarkan hasil kuesioner atau angket digital berupa umpan balik tentang pelaksanaan kegiatan pengabdian kepada masyarakat dapat diambil garis besar bahwa semua guru merasakan manfaat yang luar biasa dari adanya pelatihan ini dalam mempersiapkan pembelajaran yang berkualitas walaupun dilaksanakan dari rumah. Meskipun demikian pelatihan secara daring ini masih banyak kelemahan karena belum terjalin emosi yang kuat sebagaimana pelatihan dilaksanakan secara langsung. Setidaknya dengan adanya kegiatan ini dapat membantu guru - guru khususnya guru SD Al-Fath BSD untuk meningkatkan kompetensi pedagogik dan kompetensi profesional dalam bidang pembelajaran ini.

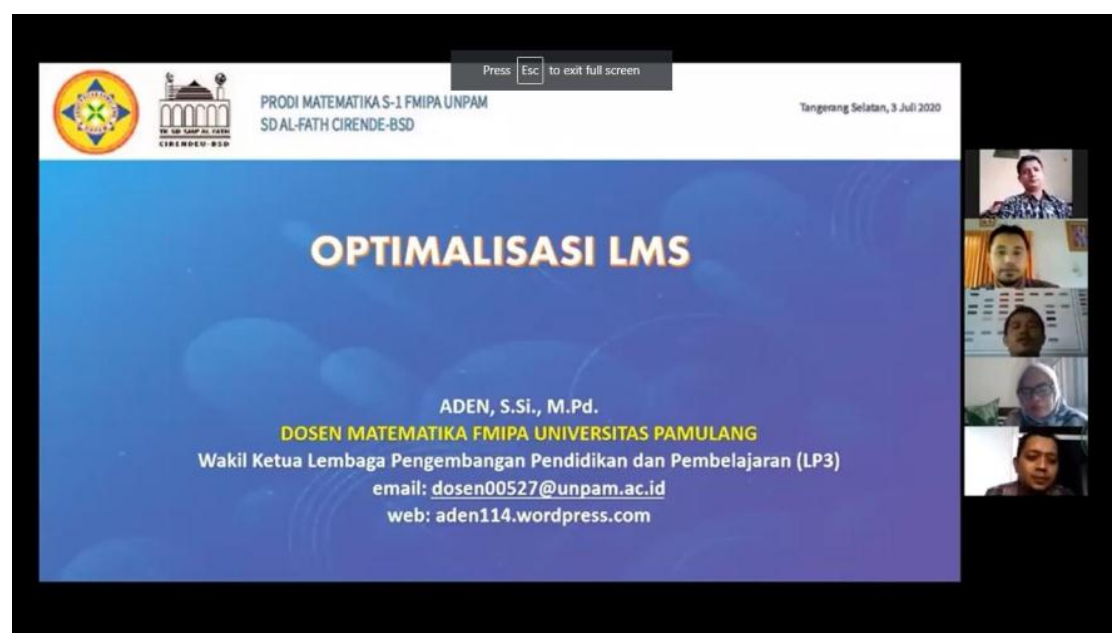

Gambar 1 Foto Kegiatan Pengabdian Kepada Masyarakat 


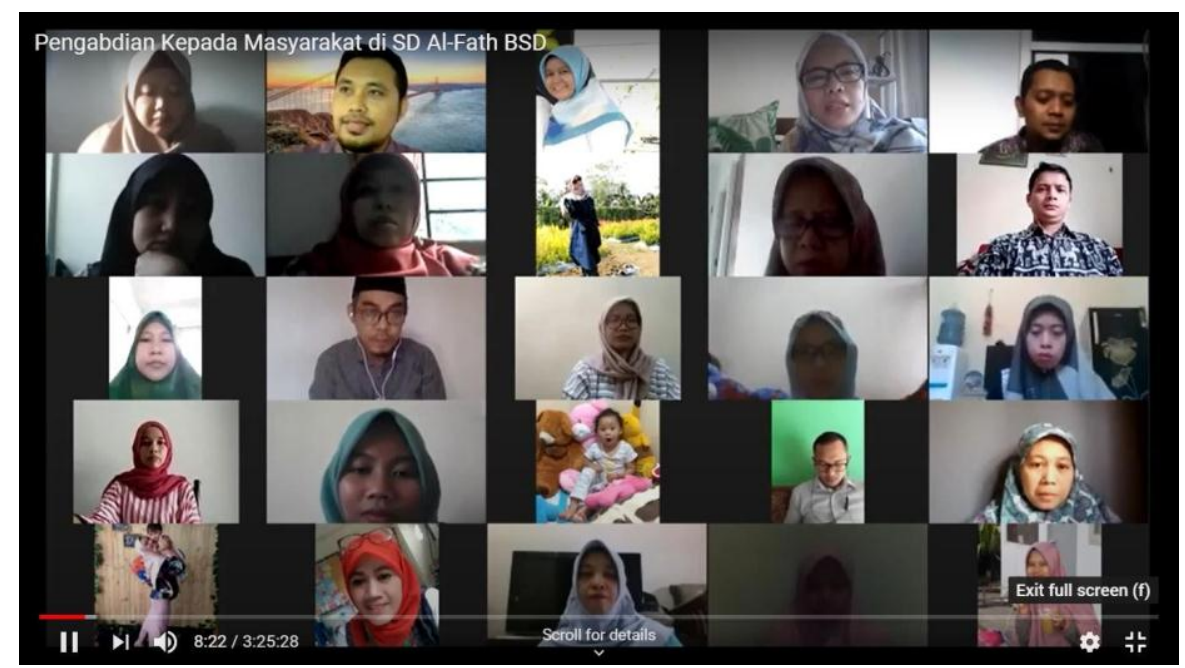

Gambar 2 Foto Kegiatan Pelatihan Daring Teknologi Pembelajaran

\section{SIMPULAN}

Berdasarkan pengamatan secara kualitatif terhadap umpan balik (feedback) angket digital yang diisi oleh peserta, dapat disimpulkan:

1). Penerapan metode pembelajaran dengan Mind Mapping melalui perangkat lunak iMindMap memudahkan proses pembelajaran secara daring khususnya untuk pendekatan pembelajaran yang berbasis active learning.

2). Guru memperoleh pengetahuan baru tentang pemanfaatan Learning Management System (LMS) berbasis Moodle untuk memudahkan tugas guru dalam memanajemen kelas, dan mampu menggunakan semua fitur-fitur yang ada pada LMS.

3). Clouding Computing komputasi awan bermanfaat sebagai sarana berkolaborasi secara daring bagi guru-guru yang selama ini mengajar dari rumah (Teaching From Home)

\section{DAFTAR PUSTAKA}

ABC. (2020, Mei 28). Belajar dari Rumah: Masih Ada Kesenjangan Pendidikan di Indonesia? Tempo.

https://www.tempo.co/abc/5637/belajar-dari-rumah-masih-ada-kesenjanganpendidikan-di-indonesia

Bona, M. (t.t.). Indonesia Dinilai Belum Siap Terapkan Pendidikan Berbasis Daring.beritasatu.com. Diambil 29 Juli 2020, dari https://www.beritasatu.com/nasional/615497-indonesia-dinilai-belum-siapterapkan-pendidikan-berbasis-daring

Buzan, T. (2008). Buku Pintar Mind Map. Gramedia Pustaka Utama. IDCloudHost. (2019, September 16). Mengenal Apa itu Cloud Computing: Defenisi, Fungsi, dan Cara Kerja. IDCloudHost.

https://idcloudhost.com/mengenal-apa-itu-cloud-computing-defenisi- fungsi-dancara-kerja/ 
Nursalikah, A. (2020, Juni 18). Guru Muhammadiyah Usulkan Pelatihan Pembelajaran Daring. Republika Online.

https://republika.co.id/share/qc430j366

Rezkisari, I. (2020, Maret 18). Belajar dari Rumah, Konsep yang Ternyata tak Mudah. Republika Online.

https://republika.co.id/share/q7ds30328

Riadi, M. (2014, Januari 3). Pengertian, Manfaat dan Membuat Mind Maping. https://www.kajianpustaka.com/2014/01/pengertian-manfaat-dan-membuatmind.html

Surjono, H. D. (2013). Membangun course e-learning berbasis moodle. Yogyakarta: UNY. Wikipedia. (2020a). Moodle. Dalam Wikipedia bahasa Indonesia, ensiklopedia bebas. https://id.wikipedia.org/w/index.php?title=Moodle\&oldid=16593650

Wikipedia. (2020b). IMindMap. Dalam Wikipedia bahasa Indonesia, ensiklopedia bebas. https://id.wikipedia.org/w/index.php?title=IMindMap\&oldid=16824729 